\title{
О возможности производства виноматериалов для игристых вин из аборигенных сортов винограда
}

\author{
Александр Семёнович Макаров, д-р техн. наук, профессор, зав. лабораторией игристых вин, makarov150@rambler.ru; \\ Игорь Павлович Лутков, канд. техн. наук, ст. науч. сотр., вед. науч. сотр. лаборатории игристых вин, igorlutkov@mail.ru; \\ Анатолий Яковлевич Яланецкий, канд. техн. наук, ст. науч. сотр., вед. науч. coтp. лаборатории тихих вин, уаl.anatol@ \\ gmail.com; \\ Наталия Александровна Шмигельская, канд. техн. наук, науч. сотр. лаборатории игристых вин, nata-ganaj@уаndex.ru; \\ Тамара Рафаиловна Шалимова, мл. науч. сотр. лаборатории игристых вин, tamaramagarach@mail.ru; \\ Виктория Алексеевна Максимовская, мл. науч. сотр. лаборатории игристых вин, lazyrit@gmail.com; \\ Валентина Васильевна Кречетова, ведущий инженер лаборатории игристых вин, kre4et@ukr.net; \\ Дмитрий Юрьевич Погорелов, науч. сотр. лаборатории химии и биохимии вина, pogdmi@ro.ru, http://orcid.org/0000- \\ 0001-6388-9706 \\ Федеральное государственное бюджетное учреждение науки «Всероссийский национальный научно-исследовательский институт \\ виноградарства и виноделия «Магарач» РАН», Россия, Республика Крым, 298600, г. Ялта, ул. Кирова, 31
}

\begin{abstract}
В статье рассмотрены физико-химические и органолептические показатели виноматериалов, выработанных из крымских и донских аборигенных сортов винограда, произрастающего в Ампелографической коллекции института «Магарач» в с. Вилино Бахчисарайского района и п. Гурзуф. Определены группы сортов, из которых получаются виноматериалы с хорошими пенистыми свойствами, оптимальным соотношением массовых концентраций винной и яблочной кислот, высокими дегустационными оценками. В частности, высокие показатели пенистых свойств $\left(\mathrm{V}_{\max }\right.$ более $800 \mathrm{~cm}^{3}$ ) определены в виноматериалах из сортов: Кокур белый 46-10-3, Кокур белый 46-10-6, Солнечная Долина 40, Солнечная Долина 71/1, Maxроватчик. Средние показатели пенистых свойств $\left(\mathrm{V}_{\max } 600-800 \mathrm{~cm}^{3}\right)$ установлены в виноматериалах из сортов: Кокур белый (п. Гурзуф), Кокур белый, Кокур белый полурассеченный, Солнечнодолинский, Солнечная Долина 31a, Солнечная Долина 65, Цимлянский белый, Кефесия, Фирский ранний (с. Вилино). Массовая концентрация винной кислоты в виноматериалах варьировала в диапазоне 1,4-4,9 г/дм³, яблочной кислоты - 0,1-3,2 г/дм³ , а лимонной - 0,1-1,2 г/дм³. Более высокая массовая концентрация винной кислоты определена в виноматериалах Сых дане $(4,9$ г/дм³), Мускат крымский $(4,7$ г/дм³), Солнечнодолинский $(4,2$ г) дм³ $^{3}$, Буланый белый $(4,2$ г/дм³), Солнечная Долина 65 (3,9 г/дм³), Кокур белый (п. Гурзуф) - (3,6 г/дм $\left.{ }^{3}\right)$, Кокур белый 46-10-3 (3,4 г/дм³), Солнечная Долина 40 (3,3 г/дм³), Махроватчик (3,3 г/дм³), Капитан Яни кара $(3,1$ г/дм³), а самая низкая - в виноматериале Цимлянский белый $(1,4$ г/дм³). Показана перспективность использования для производства виноматериалов для игристых вин из винограда аборигенных сортов: Кокур белый, Кокур белый 46-10-3, Кокур белый 46-10-6, Солнечнодолинский, Солнечная Долина 40, Солнечная Долина 65, Сых дане, Сары пандас, Мускат крымский, Махроватчик, Кокур красный, Безымянный и Цимладар.
\end{abstract}

Ключевые слова: физико-химические показатели; дегустационная оценка; качество; органические кислоты; пенистые свойства.

\section{O R I G I N A L A R T I C L E \\ On feasibility of base wine production for sparkling wines from aboriginal grapevine varieties}

\begin{abstract}
Alexander Semionovich Makarov, Igor Pavlovich Lutkov, Anatoly Yakovlevich Yalanetskiy, Natalia Aleksandrovna Shmigelskaia, Tamara Rafailovna Shalimova, Victoria Alekseevna Maksimovskaia, Valentina Vasilievna Krechetova, Dmitriy Yurievich Pogorelov

Federal State Budget Scientific Institution All-Russian National Research Institute of Viticulture and Winemaking Magarach of RAS, 31 Kirova Street, 298600 Yalta, Republic of Crimea, Russia
\end{abstract}

The article discusses physico-chemical and organoleptic characteristics of base wines produced from Crimean and Don aboriginal grapevine cultivars grown in the Ampelographic collection of the Institute "Magarach" in Vilino village of Bakhchsarai region and in Gurzuf. Groups of cultivars which provide base wines with good sparkling properties, the optimum balance between mass concentrations of tartaric and malic acids and high tasting scores have been determined. In particular, high sparkling properties $\left(V_{\max }\right.$ over $\left.800 \mathrm{~cm}^{3}\right)$ were demonstrated by base wines from the following cultivars: 'Kokur Belyi 46-10-3', 'Kokur Belyi 46-10-6', 'Solnechnaya Dolina 40', 'Solnechnaya Dolina 71/1', 'Mahrovatchik'. The average sparkling indexes $\left(\mathrm{V}_{\max } 600-800 \mathrm{~cm}^{3}\right)$ were determined for base wines from the following varieties: 'Kokur Belyi' (v. Gurzuf), 'Kokur Belyi', 'Kokur Belyi Polurassechenny', 'Solnechnodolinsky', 'Solnechnaya Dolina 31a', 'Solnechnaya Dolina 65', 'Tsimlyansky Belyi', 'Kefesiya', 'Firsky Rannyi' (v. Vilino). Mass concentration of tartaric acid in the base wine varied between

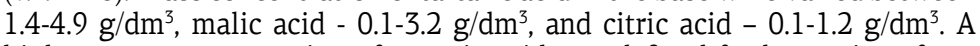
higher mass concentration of tartaric acid was defined for base wines from 'Sykh Dane' ( $\left.4.9 \mathrm{~g} / \mathrm{dm}^{3}\right)$, 'Muscat Krymskyi' $\left(4.7 \mathrm{~g} / \mathrm{dm}^{3}\right)$, 'Solnechnodolinsky' $\left(4.2 \mathrm{~g} / \mathrm{dm}^{3}\right)$, 'Bulany Belyi' $\left(4.2 \mathrm{~g} / \mathrm{dm}^{3}\right)$, 'Solnechnaya Dolina' $65\left(3.9 \mathrm{~g} / \mathrm{dm}^{3}\right)$, 'Kokur Belyi' (v. Gurzuf) - (3.6 g/dm³), 'Kokur Belyi 46-10-3' (3.4 g/ $\left./ \mathrm{dm}^{3}\right)$, 'Solnechnaya Dolina 40' (3.3 g/dm³), 'Mahrovatchik' (3.3 g/ $\left.\mathrm{dm}^{3}\right)$, 'Captain Yani Kara' $\left(3.1 \mathrm{~g} / \mathrm{dm}^{3}\right)$; the lowest in 'Tsimlyansky Belyi' grapes $\left(1.4 \mathrm{~g} / \mathrm{dm}^{3}\right)$. The potential of using indigenous varieties of grapevines for the production of base wine for sparkling wines was demonstrated for the following cultivars: 'Kokur Belyi 46-10-3', 'Kokur Belyi 46-10-6', 'Solnechnodolinsky', 'Solnechnaya Dolina 40', 'Solnechnaya Dolina 65', 'Sykh Dane', 'Sary pandas', 'Muscat Krymskui', 'Mahrovatchik', 'Kokur Krasnyi', 'Bezymyannyi' and 'Tsimladar'.

Key words: physico-chemical parameters; tasting assessment; quality; organic acids; sparkling properties.

\section{Как цитировать эту статью}

Макаров А.С., Лутков И.П., Яланецкий А.Я., Шмигельская Н.А., Шалимова Т.Р., Максимовская В.А., Кречетова В.В., Погорелов Д.Ю. О возможности производства виноматериалов для игристых вин из аборигенных сортов винограда // «Магарач». Виноградарство и виноделие, 2019; 21 (2). C. 147-152. DOI 10.35547/IM.2019.21.2.014

How to cite this article

Makarov A.S., Lutkov I.P., Yalanetskiy A.Ya, Shmigelskaia N.A., Shalimova T.R., Maksimovskaia V.A., Krechetova V.V., Pogorelov D. Yu. On feasibility of base wine production for sparkling wines from aboriginal grapevine varieties // Magarach. Viticulture and Winemaking, 2019; $21(2)$. - pp. 147-152. DOI 10.35547/IM.2019.21.2.014

удК 634.85:663.223.11(470.75)

Поступила 16.04.2019

Принята к публикации 16.05.2019

(C)Авторы, 2019 
$\mathrm{B}$ ведение. В настоящее время большое внимание уделяется аборигенным сортам винограда. Аборигенным считается сорт винограда, который произошём от Аиких видов или форм, произрастающих в Аанной местности $[1,2]$. Аборигенные сорта распространены в различных странах и регионах [2-4]. Например, к настоящему времени в Крыму произрастают 110 аборигенных сортов винограда (80 из которых растут в Судакском регионе). Среди них наиболее известны: Кокур белый, Эким кара, Ажеват кара, Кефесия, Капсельский белый, Солнечнодолинский, Сары пандас, Кок пандас, Шабаш и др. [2, 5-7]. На Аону распространены аборигенные сорта: Циммянский чёрный, Плечистик, Красностоп золотовский, Сибирьковый и ар. [8-11]. Следует отметить, что все аборигенные сорта характеризуются относительно высокой выносливостью к неблагоприятным природно-КАиматическим условиям, и, что немаловажно, из винограда этих сортов получаются качественные оригинамьные вина $[2,11,12]$. В последние годы происходит увеличение посадок крымских аборигенных сортов винограАа. Учитывая положительные свойства аборигенных сортов, их применяют также в селекционной работе, в частности, Аля скрещивания с формами разАичного происхожАения [13, 14].

На рынке винодельческой продукции вина, выработанные из аборигенных сортов винограда, занимают определённую нишу. Например, в Крыму с использованием донских аборигенных сортов Красностоп золотовский и Цимцянский чёрный произвоАят высококачественное красное столовое вино [22]; а крымские аборигенные сорта винограда Ажеват кара, Эким кара и Кефесия используют при приготов-

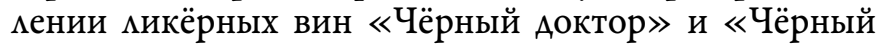
полковник». В Ростовской области готовят сортовые столовые вина «Сибирьковый», «Цимлянский чёрный» из соответствующих Аонских аборигенов. Знаменитое красное вино «Цимлянское игристое» производят из аборигенных сортов винограда Циммянский черный, Пкечистик, Буланый, Цимладар, выращиваемых в Ростовской области. В Крыму уже несколько мет (в АО «Севастопольский винзавоА») выпускают белое игристое вино «Кокур».

В Ампемографической комлекции института «Магарач» (с. Вилино, Бахчисарайского района) произрастают различные аборигенные сорта винограда, в том числе крымские и донские $[15,16]$. Учёными института «Магарач» проводились исследования по выработке виноматериалов, в том числе предназначенных Аля игристых вин, из ряда аборигенных сортов винограда: Кефесия, Капитан Яни кара, Ажеват кара, Сары пандас, Кокур белый, Шабаш, Красностоп золотовский, Цимлянский чёрный, произрастающих в Крыму и Ростовской области. И были получены предварительные положительные результаты [17-21]. ОАнако многие крымские и донские аборигенные сорта остались не исследованными на преАмет возможности применения их ААя приготовмения виноматериаАов ААя игристых вин.

Целью наших исследований являмось изучение физико-химических и органолептических показателей виноматериалов из некоторых крымских и Аонских аборигенных сортов винограАа А я установления возможности их испоцьзования в производстве игристых вин.

\section{Объекты и методы исследований}

Объектами исследований явцялись виноматериацы, выработанные из аборигенных крымских и Аонских сортов винограда урожая 2018 г., произрастающих в Ампелографической комлекции института «Магарач» (с. Вимино):

бельх - Кокур бемый 46-10-3, Кокур белый 46-106, Кокур белый полурассеченный, Кокур белый рассеченный, Сары пандас, Сых дане, Солнечнодолинский, Солнечная Аолина 40, Солнечная Аолина 71/1, Солнечная Аолина 31a, Солнечная Аолина 65, Мускат крымский, Солдайя, Махроватчик, Циммянский бе-

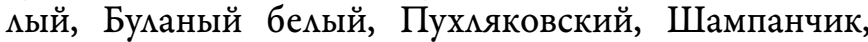
Шампанчик бессергеневский, Павмо изюм;

красных - Аемир кара, Кефесия, Капитан Яни кара, Бурый, Кокур красный, Фирский ранний, Чёрный крымский, Цимладар, Плечистик, Безымянный; а также виноматериал из винограда сорта Кокур бе$\Lambda$ ый, произрастающего в п. Гурзуф.

Аля выработки виноматериалов использоваци партии винограда с массовой концентрацией сахаров

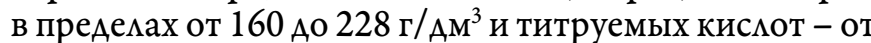
5,0 Ао 8,8 г/Ам³. Стомовые виноматериалы приготов еены в условиях микровиноделия согласно требованиям Аействующей нормативной Аокументации [23]. Аля провеАения процесса брожения использовали Арожжи из Коммекции микроорганизмов винодемия инсти-

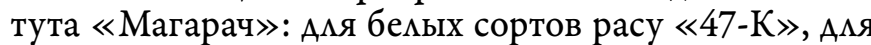
красных сортов расу «Каберне 5». Выработанные виноматериалы соответствоваци требованиям ГОСТ 32030 Вина столовые и виноматериалы столовые. Общие технические усмовия. В полученных виноматериалах определями физико-химические показатели согласно [24], в том числе пенистые свойства $\left(\mathrm{V}_{\max }\right.$ - максимацьный объём пены, см³ $^{3}$; рушения пены, с) согласно СТО 01580301.015-2017 Столовые виноматериацы Аця игристых вин, напитки, насыщенные Аиоксидом углерода. Определение пенистых свойств. Качественный и количественный состав органических кислот опреАеляли методом ВЭЖХ [25], при этом разделение пробы на индивидуацьные вещества проводики на колонке Supelcogel $\mathrm{C} 610 \mathrm{H}$ (Supelco ${ }^{\circledast}$, Sigma-Aldrich, USA), запомненной сорбентом на основе сумьфитированного Аивинил-полистирола (размер колонки 300 х 7,8, зернение сорбента не более 10,0 мкм), на хроматографе Shimadzu LC 20AD (Япония), оснащенном спектрофотометрическим и рефрактометрическим Аетектороми. В качестве элюента использоваци водный раствор ортофосфорной кислоты $\left(1\right.$ г/АM $\left.{ }^{3}\right)$.

Массовую концентрацию органических кислот в пробе вина опредемяли согласно преАварительной градуировке прибора по стандартам чистых веществ на спектрофотометрическом детекторе системы при 210 нм, с учетом времени выхода и спектрацьных характеристик кажАого из индивидуамьных веществ. В случае наличия взвесей ими нерастворимых частиц 
при визуацьной оценке пробы виноматериала, проводими предварительное их отделение при помощи центрифуги (частота вращения ротора не менее 6-7 тыс. об. в мин., Алительность - не более 5-7 мин.).

\section{Обсуждение результатов}

Результаты анализов преАставлены в табц. 1, 2 и на рис.

Из таблицы 1 следует, что объёмная Аоля этимового спирта в виноматериалах составця$\Lambda$ от 10,0 Ао $13,5 \%$, массовая концентрация титруемых кис-

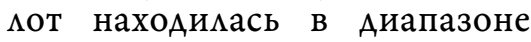
5,0-8,9 г/Ам ${ }^{3}$. Аополнительно

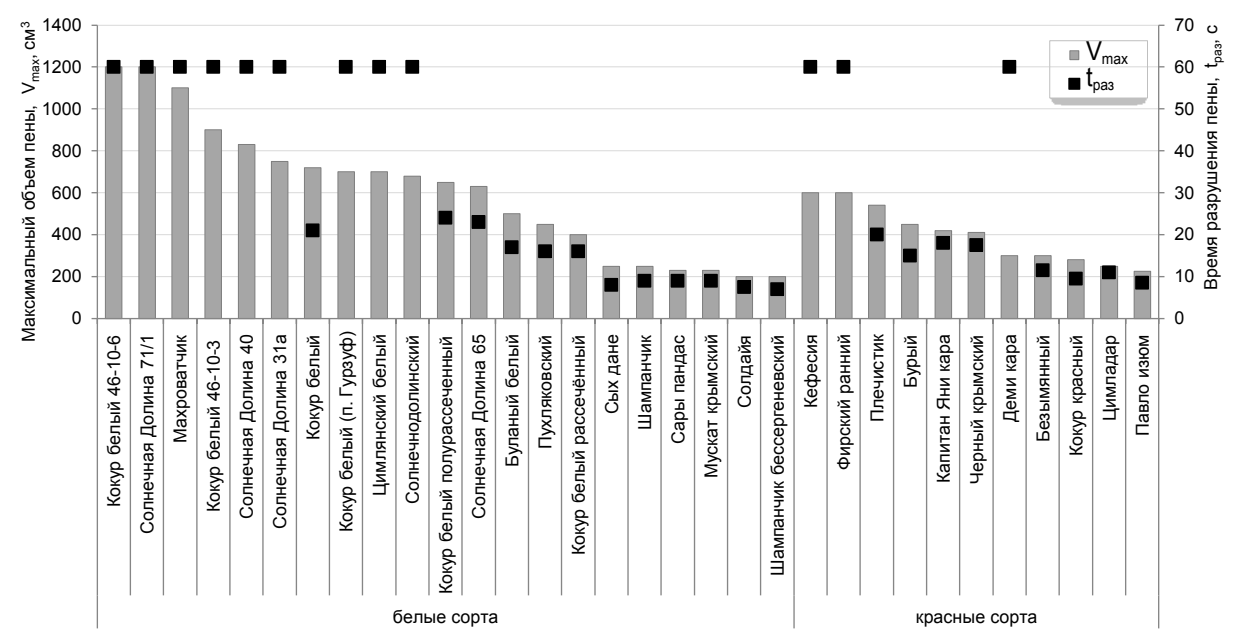

Рис. Пенистые свойства виноматериалов

Fig. Sparkling properties of base wines

Таблица 1. Физико-химические показатели виноматериалов

Table 1. Physico-chemical parameters of base wines

\begin{tabular}{|c|c|c|c|c|c|c|c|}
\hline Наименование образца & $\begin{array}{l}\text { Происхож- } \\
\text { Аение сорта }\end{array}$ & $\begin{array}{l}\text { Объёмная } \\
\text { Аоця этицо- } \\
\text { вого спирта, } \\
\%\end{array}$ & $\begin{array}{l}\text { Массовая } \\
\text { концентрация } \\
\text { титруемых } \\
\text { кисмот, г/Ам }\end{array}$ & $\begin{array}{l}\text { Массовая } \\
\text { концентрация } \\
\text { глицерина, } \\
\text { г/Ам }\end{array}$ & $\begin{array}{l}\text { Показатемь } \\
\text { жемтизны } \\
\text { (G) }\end{array}$ & $\begin{array}{l}\text { Скцонность к } \\
\text { окислитемьному } \\
\text { покоричневению }\end{array}$ & $\begin{array}{l}\text { АO, } \\
\text { бам }\end{array}$ \\
\hline \multicolumn{8}{|c|}{ Бельце сорта } \\
\hline Кокур бемый (п. Гурзуф) & K & 12,6 & 6,1 & 5,6 & 17,94 & - & 7,79 \\
\hline Кокур бемый 46-10-3 & K & 12,8 & 6,9 & 7,1 & 21,51 & + & 7,73 \\
\hline Кокур бемый 46-10-6 & K & 13,3 & 7,2 & 6,9 & 24,32 & + & 7,69 \\
\hline Кокур бемый помурассеченный & IK & 12,0 & 5,0 & $\mathrm{H}$ & 31,26 & + & 7,56 \\
\hline Кокур белый рассечённый & K & 13,5 & 6,9 & 10,5 & 29,11 & + & 7,65 \\
\hline Кокур белый & K & 12,7 & 6,4 & 5,8 & 33,14 & + & 7,69 \\
\hline Сары пандас & K & 11,5 & 6,0 & 7,3 & 15,24 & - & 7,73 \\
\hline Сых дане & K & 10,7 & 8,3 & 5,9 & 20,51 & + & 7,75 \\
\hline Солнечнодолинский & K & 11,7 & 6,5 & 6,9 & 23,62 & + & 7,69 \\
\hline Солнечная Аолина 40 & K & 12,0 & 6,8 & 6,9 & 17,69 & + & 7,71 \\
\hline Солнечная Аолина 71/1 & K & 11,2 & 5,3 & $\mathrm{H}$ & 15,48 & - & 7,50 \\
\hline Солнечная Аолина 31а & K & 11,2 & 5,0 & $\mathrm{H}$ & 35,47 & + & 7,50 \\
\hline Солнечная Аолина 65 & K & 12,6 & 7,7 & 6,7 & 27,73 & + & 7,70 \\
\hline Мускат крымский & K & 10,0 & 8,9 & 6,0 & 12,20 & - & 7,73 \\
\hline Сомдайя & K & 11,0 & 5,1 & $\mathrm{H}$ & 11,67 & - & 7,56 \\
\hline Махроватчик & A & 10,9 & 5,9 & 5,1 & 16,07 & + & 7,68 \\
\hline Циммянский бемый & A & 11,0 & 5,1 & 7,0 & 17,17 & + & 7,59 \\
\hline Буланый бемый & A & 10,0 & 6,2 & 5,3 & 15,82 & + & 7,66 \\
\hline Пухияковский & A & 11,3 & 5,2 & 6,0 & 13,09 & + & 7,67 \\
\hline Шампанчик & $A$ & 10,7 & 6,5 & 5,9 & 18,99 & + & 7,50 \\
\hline Шампанчик бессергеневский & A & 13,1 & 6,3 & 7,1 & 22,35 & + & 7,69 \\
\hline Пав о изюм & A & 10,3 & 5,0 & $\mathrm{H}$ & 26,12 & + & 7,50 \\
\hline \multicolumn{8}{|c|}{ Красные сорта } \\
\hline Аеми кара & K & 10,8 & 8,7 & 7,1 & $\mathrm{H}$ & $\mathrm{H}$ & 7,61 \\
\hline Кефесия & K & 10,4 & 6,0 & 6,2 & $\mathrm{H}$ & $\mathrm{H}$ & 7,51 \\
\hline Капитан Яни кара & K & 10,7 & 8,1 & 9,0 & $\mathrm{H}$ & $\mathrm{H}$ & 7,50 \\
\hline Кокур красный & K & 12,6 & 6,5 & 9,3 & $\mathrm{H}$ & $\mathrm{H}$ & 7,72 \\
\hline Фирский ранний & $A$ & 10,1 & 5,0 & $\mathrm{H}$ & $\mathrm{H}$ & $\mathrm{H}$ & 7,51 \\
\hline Черный крымский & A & 10,3 & 6,3 & 8,4 & $\mathrm{H}$ & $\mathrm{H}$ & 7,58 \\
\hline Бурый & A & 11,6 & 6,1 & 8,1 & $\mathrm{H}$ & $\mathrm{H}$ & 7,61 \\
\hline Цимладар & A & 13,4 & 6,5 & 8,4 & $\mathrm{H}$ & $\mathrm{H}$ & 7,68 \\
\hline Пкечистик & A & 10,0 & 5,4 & 7,6 & $\mathrm{H}$ & $\mathrm{H}$ & 7,50 \\
\hline Безымянный & A & 11,6 & 6,6 & 7,3 & $\mathrm{H}$ & $\mathrm{H}$ & 7,64 \\
\hline
\end{tabular}

Примечания: К - крымский; А - Аонской; Н - показатель не опредемялся; «+» - скмонен, «-» - не скмонен; $А \mathrm{O}$ - Аегустационная оценка. В красных виноматериалах показатели желтизны и скмонности к окислительному покоричневению не опредеАяются. 
On feasibility of base wine production

for sparkling wines from aboriginal grapevine varieties

к основным контролируемым показателям определями содержание глицерина, который участвует в формировании вкуса виноматериацов, обеспечивая им мягкость; а также повышает вязкость виноматериалов, что благоприятно вмияет на формирование типичных свойств игристых вин.

ОАним из критериев оценки внешнего вида виноматериацов явмяется характеристика его окраски. Алябелых виноматериацов, испомьзуемых Амя производства игристых вин, кроме сенсорной характеристики испоцьзуют анацитический - показатель желтизны, который в исследуемых виноматериалах нахоАился в Аиапазоне от 11,67 Ао 35,47, что в бомьшинстве вариантов превышает рекомендуемые оптимацьные значения [26]. Также установмено, что практически все виноматериалы скмонны к окислительному покоричневению, за искмючением виноматериалов из сортов Кокур бемый (п. Гурзуф), Сары пандас, Сомнечная Аолина 71/1, Мускат крымский, Сомдайя (с. Вимино), что свидетемьствует о перспективности их испоцьзования в шампанизации с выдержкой. В остальных случаях необходимо применение технологических операций на всех стаАиях производства игристых вин, способствующих снижению прохожАения окислительных процессов в виноматериалах.

При оценке типичных свойств виноматериалов выяв ено, что высокие показатели пенистых свойств $\left(\mathrm{V}_{\max }\right.$ более $\left.800 \mathrm{~cm}^{3}\right)$ [27] определены в виноматериалах из сортов: Кокур бемый 46-10-3, Кокур бемый 46-10-6, Сомнечная Аолина 40, Сомнечная Аомина 71/1, Махроватчик. Средние показатели пенистых свойств $\left(\mathrm{V}_{\max } 600-800 \mathrm{~cm}^{3}\right)$ установлены в виноматериалах из сортов: Кокур бемый (п. Гурзуф), Кокур бемый, Кокур бемый полурассеченный, Солнечнодолинский, Солнечная Аолина 31a, Солнечная Аомина 65, Циммянский бемый, Кефесия, Фирский ранний (с. Викино) (рис.).

Хорошая устойчивость пены $\left(\mathrm{t}_{\mathrm{pa}}\right.$ бомее $\left.60 \mathrm{c}\right)$ установмена в образцах: Кокур бемый (п. Гурзуф), Кокур бемый 46-10-3, Кокур бемый 46-10-6, Сомнечнодолинский, Сом-
Makarov A.S., LutkovI.P., Yalanetskiy A.Ya, Shmigelskaia N.A.,

Shalimova T.R., Maksimovskaia V.A., Krechetova V.V., Pogorelov D. Yu.

WINEMAKING

Таблица 2. Массовые концентрации органических кислот в виноматериалах Table 2. Mass concentrations of organic acids in base wines

\begin{tabular}{|c|c|c|c|c|c|c|c|}
\hline \multirow[b]{2}{*}{ Наименование образца } & \multirow{2}{*}{$\begin{array}{l}\text { Про- } \\
\text { ис- } \\
\text { хожде- } \\
\text { ние } \\
\text { сорта }\end{array}$} & \multicolumn{5}{|c|}{$\begin{array}{l}\text { Массовая концентрация кислот, } \\
\text { г/AM }{ }^{3}\end{array}$} & \multirow{2}{*}{$\begin{array}{l}\text { Соотно- } \\
\text { шение мас- } \\
\text { совых кон- } \\
\text { центраций } \\
\text { винной и } \\
\text { ябцочной } \\
\text { кис от }\end{array}$} \\
\hline & & $\begin{array}{l}\text { вин- } \\
\text { ной }\end{array}$ & $\begin{array}{l}\text { ябцоч- } \\
\text { ной }\end{array}$ & $\begin{array}{l}\text { момоч- } \\
\text { ной + } \\
\text { янтар- } \\
\text { ной }\end{array}$ & $\begin{array}{l}\text { АИ- } \\
\text { мон- } \\
\text { Ной }\end{array}$ & $\begin{array}{l}\text { уксус- } \\
\text { ной }\end{array}$ & \\
\hline
\end{tabular}

\begin{tabular}{|c|c|c|c|c|c|c|c|}
\hline \multicolumn{8}{|c|}{ Бельге сорта } \\
\hline Кокур бемый (п. Гурзуф) & K & 3,6 & 1,3 & 0,9 & 0,2 & 0,3 & 2,77 \\
\hline Кокур бемый 46-10-3 & K & 3,4 & 1,4 & 0,9 & 0,9 & 0,1 & 2,43 \\
\hline Кокур бемый 46-10-6 & K & 2,9 & 1,7 & 0,9 & 0,6 & 0,2 & 1,71 \\
\hline Кокур бемый рассечённый & K & 2,1 & 1,4 & 1,3 & 1,1 & 0,2 & 1,50 \\
\hline Кокур бемый & K & 3,0 & 1,1 & 0,8 & 0,5 & 0,2 & 2,73 \\
\hline Сары пандас & K & 2,6 & 1,6 & 1,2 & 1,2 & 0,2 & 1,63 \\
\hline Сых дане & K & 4,9 & 1,4 & 1,1 & 0,7 & 0,3 & 3,50 \\
\hline Солнечнодолинский & K & 4,2 & 0,7 & 0,8 & 0,3 & 0,2 & 6,00 \\
\hline Сомнечная Аомина 40 & K & 3,3 & 2,3 & 1,0 & 0,7 & 0,1 & 1,44 \\
\hline Сомнечная Аомина 65 & K & 3,9 & 1,9 & 0,9 & 0,6 & 0,2 & 2,05 \\
\hline Мускат крымский & K & 4,7 & 1,3 & 1,0 & 1,0 & 0,2 & 3,62 \\
\hline Махроватчик & $A$ & 3,3 & 1,0 & 0,7 & 0,4 & 0,2 & 3,30 \\
\hline Цимлянский бемый & $A$ & 1,4 & 1,4 & 0,7 & 1,2 & 0,4 & 1,00 \\
\hline Буманый бемый & $A$ & 4,2 & 1,0 & 0,9 & 0,4 & 0,2 & 4,20 \\
\hline Пухияковский & $A$ & 2,7 & 0,9 & 1,0 & 0,4 & 0,2 & 3,00 \\
\hline Шампанчик & $A$ & 2,6 & 3,2 & 1,0 & 1,1 & 0,2 & 0,81 \\
\hline Шампанчик бессергеневский & $A$ & 2,7 & 1,0 & 1,6 & 1,1 & 0,4 & 2,70 \\
\hline \multicolumn{8}{|c|}{ Kраснье сорта } \\
\hline Аеми кара & K & 2,8 & 1,1 & 4,2 & 0,6 & 0,3 & 2,55 \\
\hline Кефесия & K & 2,9 & 0,7 & 1,0 & 0,2 & 0,4 & 4,14 \\
\hline Капитан Яни кара & K & 3,1 & 1,4 & 1,0 & 0,4 & 0,3 & 2,21 \\
\hline Кокур красный & $\mathrm{K}$ & 2,3 & 0,8 & 1,9 & 0,3 & 0,4 & 2,88 \\
\hline Черный крымский & K & 2,8 & 0,9 & 1,5 & 0,9 & 0,3 & 3,11 \\
\hline Бурый & $A$ & 2,2 & 0,1 & 2,1 & 0,4 & 0,5 & 22,0 \\
\hline Цимладар & $A$ & 2,3 & 0,7 & 0,9 & 0,5 & 0,8 & 3,29 \\
\hline Плечистик & $A$ & 2,2 & 0,3 & 1,9 & 0,1 & 0,9 & 7,33 \\
\hline Безымянный & $A$ & 2,2 & 0,7 & 1,5 & 0,6 & 0,5 & 3,14 \\
\hline
\end{tabular}

Примечания: К - крымский; А - Аонской.

нечная Аолина 40, Солнечная Аолина 71/1, Солнечная Аолина 31a, Махроватчик, Цимлянский белый, Кефесия, Аеми кара, Фирский ранний (рис.).

Из таблицы 2 видно, что массовая концентрация винной кислоты в виноматериацах варьировала в Аиапазоне 1,4-4,9 г/Ам ${ }^{3}$, яблочной кислоты 0,1-3,2 г/Ам ${ }^{3}$, а имонной 0,1-1,2г/Ам ${ }^{3}$. Более высокая массовая концентрация винной кислоты определена в виноматериалах Сых Аане (4,9 г/Ам³),

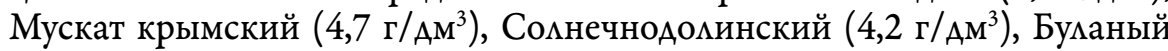
белый $\left(4,2\right.$ г/Ам $\left.{ }^{3}\right)$, Солнечная Аолина 65 (3,9 г/Ам³ $)$, Кокур белый (п. Гурзуф) - (3,6 г/Ам $\left.{ }^{3}\right)$, Кокур белый 46-10-3 (3,4 г/Ам³ $)$, Солнечная Аолина 40 $\left(3,3\right.$ г/АM $\left.{ }^{3}\right)$, Махроватчик $\left(3,3\right.$ г/Ам $\left.{ }^{3}\right)$, Капитан Яни кара $\left(3,1\right.$ г/АM $\left.{ }^{3}\right)$, а самая низкая - в виноматериале Цимлянский белый $\left(1,4 \mathrm{\Gamma} / \mathrm{AM}^{3}\right)$. Более высокая концентрация яблочной кислотывыявленав виноматериахах Шампанчик $\left(3,2\right.$ г/ $\left.\mathrm{AM}^{3}\right)$ и Солнечная Аолина $40\left(2,3\right.$ г/ $\left.\mathrm{AM}^{3}\right)$, а самая низкая - в виноматериале Бурый $\left(0,1 \mathrm{r} / \mathrm{AM}^{3}\right)$. Соотношение винной и яблочной кислот во всех виноматериалах, за искцючением виноматериала из сорта Шампанчик, было $\geq 1$, что положительно влияет на качество готовой продук- 
ции [28-30]. В некоторых образцах виноматериалов из красных сортов Аеми кара, Бурый, Кокур красный, Чёрный крымский, Плечистик и Безымянный установцено более высокое содержание молочной кислоты (1,5-4,2 г/ $\left.\mathrm{AM}^{3}\right)$ при невысокой массовой концентрации яблочной кислоты $\left(0,1-1,1\right.$ г/Ам $\left.{ }^{3}\right)$, это свидете ьствует о пройденном процессе яблочно-молочного брожения, что положительно сказывается на вкусовых характеристиках [31].

Наиболее высокие Аегустационные оценки в балмах получими образцы из сортов: Кокур бемый (п. Гурзуф) - 7,79, Сых дане - 7,75, Сары пандас - 7,73, Кокур бемый 46-10-3 - 7,73, Мускат крымский - 7,73, Кокур красный - 7,72, Солнечная Аолина 40 - 7,71, Солнечная Аолина 65 - 7,70 (с. Вимино) (табл. 1).

Выводы. Таким образом, по совокупности проведенных исследований физико-химических показателей

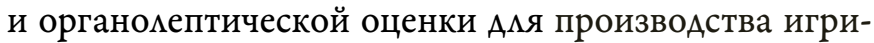
стых вин преАставцяют интерес виноматериалы из аборигенных сортов: Кокур белый, Кокур белый 4610-3, Кокур белый 46-10-6, Сомнечнодоминский, Сомнечная Аолина 40, Солнечная Аолина 65, Сых Аане, Сары пандас, Мускат крымский, Махроватчик, Кокур красный, Безымянный и Цимкадар.

Исследования в этом направцении планируется проАоцжить.

\section{Источник финансирования}

Работа выполнена в рамках Государственного заАания № 0833-2014-0014.

\section{Financing source.}

The study was conducted under public assignment № 0833-2014-0014.

\section{Конфликт интересов Не заявмен.}

\section{Conflict of interests}

No declared.

\section{Список литературы/Reference}

1. Энциклопедия виноградарства: в 3-х томах. - Кишинёв: Гл. ред. Молд. Сов. Энциклопедии, 1986. - Т. 1. - С.9

Enciklopediya vinogradarstva: v3-b tomah. [Encyclopedia of Viticulture in 3 volumes]. - Kishinyov: Ch. Ed. Mold. Sov. Encyclopedia, 1986. Vol. 1. - p.9. (in Russian)

2. Лиховской В.В., Зармаев А.А., Полулях А.А., Волынкин В.А., Гориславец С.М., Рисованная В.И., Борисенко М.Н., Сапсай А.О. Ампелография аборигенных и местных сортов Крыма: монография под ред. Лиховского В.В. - Симферополь: ООО «Форма», 2018. - 140 с.

Lihovskoi V.V., Zarmaev A.A., Polulyah A.A., Volynkin V.A., Gorislavec S.M., Risovannaya V.I., Borisenko M.N., Sapsaj A.O. Ampelografiya aborigennyb $i$ mestnyh sortov Kryma: monografiya pod red. Libouskogo V.V. [Ampelography of the aboriginal and local varieties of Crimea: Monograph under the editorship of Likhovskoi V.V.]Simferopol': O00 Forma, 2018. - 140 p. (in Russian)

3. Трошин Л.П. Аборигенные сорта винограда России/ Л.П. Трошин. - Краснодар: Куб ГАУ, 2007. - 256 с.

Troshin L.P. Aborigennye sorta vinograda Rossii/ L.P. Troshin. Krasnodar: Kub GAU, 2007. - 256 p. (in Russian)

4. Меркуропулос Г., Мелиордос Д-Э., Хатзопулос П., Котсеридис Й. В поисках неизвестных греческих автохтонных сортов винограда на полуострове Пелопоннес - предварительные результаты // «Магарач». Виноградарство и виноделие. - 2018. - №4. - С. 51-53.

Merkuropulos G., Meliordos D-E., Hatzopulos P., Kotseridis J. $V$ poiskah neizvestnyh grecheskih avtohtonnyh sortov vinograda na poluostrove Peloponnes - predvaritel'nye rezul'taty [Searching for unknown greek indigenous grapevine varieties from Peloponnesus - initial results]// "Magarach". Vinogradarstvo i vinodelie. [Magarach. Viticulture and Winemaking]. - 2018. - №4. - pp. 51-53. (in Russian)

5. Зармаев А.А., Борисенко М.Н. Исторические корни ампелографии и пути сохранения генофонда винограда в ФГБУН «ВННИИВиВ «Магарач» РАН». Часть 1// «Магарач». Виноградарство и виноделие. - 2017. - №3. - С. 3-6.

Zarmaev A.A., Borisenko M.N. Istoricheskie korni ampelografii $i$ puti sobraneniya genofonda vinograda v FGBUN «VNNIIViV «Magarach» $R A N »$. Part 1 The historical roots of ampelography and the ways to preserve the grapevine gene pool at the institute "Magarach" of the Russian Academy of Sciences] // "Magarach". Vinogradarstvo $i$ vinodelie. [Magarach. Viticulture and Winemaking]. - 2017. - №3.pp. 3-6. (in Russian)

6. Иванов А.А. Крымские аборигенные сорта винограда. - Симферополь: Крымиздат, 1947.- 79 с.

Ivanov A.A. Krymskie aborigennye sorta vinograda. - Simferopol': Krymizdat, 1947. - 79 p. (in Russian)

7. Тараненко В.В. Крымские аборигенные сорта винограда // Виноградарство и виноделие: Сб. науч. тр. НИВиВ «Магарач». Том 44. - Ялта, 2014. - С. 14-16.

Taranenko V.V. Krymskie aborigennye sorta vinograda//Vinogradarstvo i vinodelie: Sb. nauch. tr. NIViV 'Magarach'. Vol. 44. - Yalta, 2014. pp. 14-16. (in Russian)

8. Аборигенные сорта винограда http:/grapes.hozvo.ru/ aborigennie_sorta-91911.

Aborigennye Sorta vinograda http://grapes.hozvo.ru/aborigennie sorta- 91911 (in Russian)

9. Наумова Л.Г., Новикова Л.Ю. Температурные потребности аборигенных донских сортов винограда в регионе происхождения// «Магарач». Виноградарство и виноделие. - 2016. - №4. - С. 10-13.

Naumova L.G., Novikova L.Yu. Temperaturnye potrebnosti aborigennyh donskih sortov vinograda v regione proiskbozhdeniya [The temperature requirements of local don grape varieties in the region of origin] // "Magarach". Vinogradarstvo $i$ vinodelie. [Magarach. Viticulture and Winemaking]. - 2016. - №4. - pp. 10-13. (in Russian)

10. Наумова Л.Г., Ганич В.А. Сохранение и изучение генофонда автохтонных донских сортов винограда на коллекции ВНИИВиВ им. Я.И. Потапенко// «Магарач». Виноградарство и виноделие. - 2017. - №1. - C. 9-13.

Naumova L.G., Ganich V.A. Sobranenie $i$ izuchenie genofonda avtohtonnyb donskih sortov vinograda na kollekcii VNIIViV im. YA.I. Potapenko [Preservation and study of the gene pool of autochthonous Don grapevine varieties of the region in the collection of VNIIViV named after Ya. I. Potapenko]. "Magarach". Vinogradarstvo $i$ vinodelie. [Magarach. Viticulture and Winemaking]. - 2017. - №1. pp. 9-13. (in Russian)

11. Наумова Л.Г., Ганич В.А., Матвеева Н.В. Белобуланный - перспективный аборигенный сорт винограда для качественного виноделия// «Магарач». Виноградарство и виноделие. - 2017. - №2. - С. $10-13$.

Naumova L.G., Ganich V.A., Matveeva N.V. Belobulannyj-Perspektivnyj aborigennyj sort vinograda dlya kachestvennogo vinodeliya [Belobulany - promising aboriginal grape variety for quality wine]// "Magarach". Vinogradarstvo $i$ vinodelie. [Magarach. Viticulture and Winemaking]. - 2017. - № 2. - pp. 10-13. (in Russian)

12. Jackson D.J., Lombard P.B. Environ-mental and Management Practices Affecting Grape Composition and Wine Quality// A Review Department of Horticulture \& Landscape: Lincoln University, Vitic, 1993. - V.44. №4. - pp. 409-430.

13. Лиховской В.В. Скрещиваемость крымских аборигенных сортов винограда с формами различного происхождения/ В.В. Лиховской, В.А. Волынкин, Н.П. Олейников, И.А. Васылык, Л.П. Трошин // Научный журнал Куб ГАУ. - 2015. - №114 (10). - С. 1090-1105.

Lihovskoi V.V. Skreshchivaemost' krymskib aborigennyb sortov vinograda s formami razlichnogo proiskbozhdeniya/ V.V. Lihovskoi, V.A. Volynkin, N.P. Olejnikov, I.A. Vasylyk, L.P. Troshin // Nauchnyj zhurnal Kub GAU [Scientific Journal of Kub GAU]. - 2015. - №114 (10). - pp. 1090-1105. (in Russian)

14. Полулях А.А., Лиховской В.В., Волынкин В.А., Борисенко М.Н., Олейников Н.П., Васылык И.А., Трошин Л.П. Перспективный сорт селекции института «Магарач» Кефресия Магарача // «Магарач». Виноградарство и виноделие. - 2016. - №4. - С. 6-7. 
Polulyah A.A., Lihovskoi V.V., Volynkin V.A., Borisenko M.N., Olejnikov N.P., Vasylyk I.A., Troshin L.P. Perspektionyj sort selekcii instituta "Magarach" Kefesiva Magaracha [Kefesiva Magaracha - a promising grape variety of the Institute Magarach breeding] // "Magarach". Vinogradarstvo $i$ vinodelie. [Magarach. Viticulture and Winemaking] - 2016. - №4. - pp. 6-7. (in Russian)

15. Волынкин В.А., Полулях А.А., Чижова А.М. Каталог ампелографической коллекции Института винограда и вина «Магарач». Часть 1. Аборигенные и местные сорта Крыма. - Ялта: ИВиВ «Магарач», 2004. -20 c.

Volynkin V.A., Polulyah A.A., Chizhova A.M. Katalog ampelograficheskoj kollekcii Instituta vinograda i vina "Magarach». Part 1. Aborigennye i mestnye sorta Kryma. - Yalta: IViV "Magarach", 2004. - 20 p. (in Russian)

16. Полулях А.А., Волынкин В.А., Лиховской В.В. Ампелография и агробиология автохтонных сортов винограда Крыма: сорт Солнечнодолинский // «Магарач». Виноградарство и виноделие. - 2017. - №2. - C. 7-10.

Polulyah A.A., Volynkin V.A., LihovskojV.V. Ampelografiya iagrobiologiva avtohtonnyb sortov vinograda Kryma: sort Solnechnodolinskij Ampelography and agrobiology of the Crimean autochtonous grape varieties: Solnechnodolinsky variety]// "Magarach". Vinogradarstvo $i$ vinodelie. [Magarach. Viticulture and Winemaking]. - 2017. - №2. pp. 7-10. (in Russian)

17. Остроухова Е.В., Пескова И.В., Пробейголова П.А., Луткова Н.Ю. Анализ технологических параметров винограда крымских аборигенных сортов: разработка информационных моделей // «Магарач». Виноградарство и виноделие. - 2018. - № 2 (104) . - С. 31-34.

Ostrouhova E.V., Peskova I.V., Probejgolova P.A., Lutkova N.Yu. Analiz tekbnologicheskih parametrov vinograda krymskib aborigennyb sortov: razrabotka informacionnyh modelej [Analysis of the technological parameters of the Crimean autochthonous grape varieties: development of information models] // "Magarach". Vinogradarstvo i vinodelie. [Magarach. Viticulture and Winemaking] - 2018. - № 2 (104). - pp. 31-34. (in Russian)

18. Макаров А.С., Лутков И.П., Шалимова Т.Р., Бурдинская А.В., Жилякова Т.А., Аристова Н.И. Исследование катионного состава виноматериалов для игристых вин, выработанных в различных хозяйствах Крыма // Плодоводство и виноградарство Юга России. - 2016. №39(03) . - C. 1-12. http://journal.kubansad.ru/pdf/16/03/06.pdf.

Makarov A.S., Lutkov I.P., Shalimova T.R., Burdinskaya A.V., Zhilyakova T.A., Aristova N.I. Issledovanie kationnogo sostava vinomaterialov dlya igristyh vin, vyrabotannyh v razlichnyh hozyajstvah Kryma /I Plodovodstvo i vinogradarstvo Yuga Rossii. - 2016. - № 39(03). - pp. 1-12. http://journal.kubansad.ru/pdf/16/03/06.pdf. (in Russian)

19. Авидзба А.М., Макаров А.С., Яланецкий А.Я., Шмигельская Н.А., Лутков И.П., Шалимова Т.Р., Максимовская В.А., Кречетова В.В. Исследование качества виноматериалов из различных сортов винограда для возможного использования их в производстве игристых вин// «Магарач». Виноградарство и виноделие. - 2017. - №2. - C. 31-35.

Avidzba A.M., Makarov A.S., Yalaneckij A.Ya., Shmigel'skaya N.A., Lutkov I.P., Shalimova T.R., Maksimovskava V.A., Krechetova V.V. Issledovanie kachestva vinomaterialov iz razlichnyb sortov vinograda dlya vozmozhnogo ispol'zovaniya ib $v$ proizvodstve igristyb vin [Quality of wine materials from grapes of different varieties for their possible use in the production of sparkling wines]// "Magarach". Vinogradarstvo $i$ vinodelie. [Magarach. Viticulture and Winemaking]. - 2017. - №2. - pp. 31-35. (in Russian)

20. Макаров А.С., Лутков И.П., Пескова И.В., Пробейголова П.А., Шалимова Т.Р., Ульянцев С.О. Влияние штамма дрожжей на показатели химического состава и качество красных игристых вин // Плодоводство и виноградарство Юга России. - 2018. - №50(02). - C. 111-122.

Makarov A.S., Lutkov I.P., Peskova I.V., Probejgolova P.A., Shalimova T.R., Ul'yancev S.O. Vliyanie shtamma drozhzhej na pokazateli bimicheskogo sostava i kachestvo krasnyb igristyb vin // Plodovodstvo i vinogradarstvo Yuga Rossii. - 2018. - №50(02). - pp. 111-122. (in Russian)

21. Остроухова Е.В., Пескова И.В., Погорелов Д.Ю. Профиль органических кислот винограда белых сортов, произрастающих в
Крыму// Плодоводство и виноградарство Юга России. - 2019. №56(02) - - C. 122-132.

Ostrouhova E.V., Peskova I.V., Pogorelov D.Yu. Profil' organicheskih kislot vinograda belyh sortov, proizrastayushchib v Krymull Plodovodstvo i vinogradarstvo Yuga Rossii. - 2019. - №56(02). - pp. 122-132. (in Russian)

22. Бронавицкая Т.Ю., Макагонов Ю.А., Макагонов А.Ю. Подбор сортов винограда для производства красных сухих вин в совхозузаводе «Алушта»// «Магарач». Виноградарство и виноделие. 2005. - №2. - C. 30-31.

Bronavickaya T.Yu., Makagonov Yu.A., Makagonov A.Yu. Podbor sortov vinograda dlya proizvodstva krasnyb subih vin $v$ sovboz-zavode Alushta [Selection of grape varieties to produce red dry wines on the state farm Alushta] // "Magarach". Vinogradarstvo i vinodelie. [Magarach. Viticulture and Winemaking]. - 2005. - №2. - pp. 30-31. (in Russian)

23. Сборник основных правил, технологических инструкций и нормативных материалов по производству винодельческой продукции/ Под общей ред. Н.Г. Саришвили/Утв. Министерством сельского хозяйства и продовольствия РФ 5 мая 1998 г. - М.: Пищепромиздат, 1998. - 242 c

Sbornik osnowny pravil, tekhnologicheskih instrukcij i normativnyh materialov po proizvodstvu vinodel'cheskoj produkcii/ Under the editorship of N.G. Sarishvili/ Utv. Ministerstvom sel'skogo bozyajstva i prodovol'stviva RF 5 maya 1998 g. - M.: Pishchepromizdat, 1998. 242 p. (in Russian)

24. Методы технохимического контроля в виноделии/ Под ред. Гержиковой В.Г. - 2-е изд. - Симферополь: Таврида, 2009. - 304 с.

Metody tekhnobimicheskogo kontrolya v vinodelii/Under the editorship of Gerzhikova V.G. - 2nd edition - Simferopol': Tavrida, 2009. - 304 p. (in Russian)

25. Аникина Н.С., Гержикова В.Г., Гниломедова Н.В., Погорелов Д.Ю. Методология идентификации подлинности вин. - Симферополь: Диайпи, 2017. - 152 с.

Anikina N.S., Gerzhikova V.G., Gnilomedova N.V., Pogorelov D.Yu. Metodologiva identifikacii podlinnosti vin. - Simferopol': Diajpi 2017. - 152 p. (in Russian)

26. Макаров А.С., Загоруйко В.А., Ходаков А.Л., Мацко А.П. Комплексная оценка качества виноматериалов для производства шампанских и белых игристых вин// ВиноГрад. - 2008. - №3 (3). - C. 30-31.

Makarov A.S., Zagorujko V.A., Hodakov A.L., Macko A.P. Kompleksnaya ocenka kachestva vinomaterialov dlya proizvodstva shampanskih $i$ belyh igristyb vin// VinoGrad. - 2008. - №3 (3). - pp. 30-31. (in Russian)

27. Колосов С.А. Влияние сортовой особенности винограда на пенообразующую способность виноматериалов// Виноградарство и виноделие: Сб. науч. тр. ИВиВ «Магарач». - 2003. - С. 87-90.

Kolosov S.A. Vliyanie sortovoj osobennosti vinograda na penoobrazuyushchuvu sposobnost' vinomaterialov// Vinogradarstvo i vinodelie: Sh. nauch. tr. IViV "Magarach". - 2003. - pp. 87-90.

28 Валуйко Г.Г., Зинченко В.И., Косюра В.Т., Яланецкий А.Я., Задорожный В.Я. Разработка и внедрение технологических приёмов комплексной стабилизации игристых вин завода «Новый Свет» (комплекс организационно-технических мероприятий и научных исследований по повышению качества). - Ялта - Симферополь - Новый Свет, 1998. - 54 с.

Valujko G.G., Zinchenko V.I., Kosyura V.T., Yalaneckij A.Ya., Zadorozhnyj V.Ya. Razrabotka $i$ unedrenie tekbnologicheskih priyomou kompleksnoj stabilizacii igristyb vin zavoda "Novyj Svet" (kompleks organizacionno-tekbnicheskih meroprivatij i nauchnyb issledovanij po povysheniyu kachestva). - Yalta - Simferopol' - Novyj Svet, 1998. $-54 \mathrm{p}$. (in Russian)

29. Soyer Y. Organic acid profile of Turkish white grapes and grape juices/Y. Soyer, N. Koca, F. Karadeniz// Journal of Food Composition and Analysis. - 2003. - № 16. - P. 629-636.

30. Danilewicz John C. Role of Tartaric and Malic Acids in Wine Oxidation/ John C. Danilewicz // J. Agric. Food Chem. - 2014. - 62 (22). - P 5149-5155.

31. Kučerová J. Study of changes organic acids in red wines during malolactic fermentation/J. Kučerová, J. Široky // Acta Univ. Agric. Silvic. Mendel. Brun. - 2014. - № 59(5). - P. 145-150. 